\title{
Adaptation of Ukrainian water resource assessment to European legislation
}

\author{
Mykola Yatsiuk, Yurii Nabyvanets, Nataliia Osadcha \\ Ukrainian Hydrometeorological Institute of the Ministry on Emergencies of Ukraine and National Academy of Science \\ of Ukraine, Prospekt Nauki,37,03028Kiev,Ukraine,e-mail: krava@uhmi.org.ua
}

\begin{abstract}
The main conceptual approaches of water quality assessment and existing methods of standardization and classification of water on various parameters were summarized. Comparative analysis of sanitary and environmental principles of standardization has been fulfilled; the advantages and disadvantages of these approaches were discussed. It was concluded that the most reliable information about the state of the aquatic ecosystem can be obtained by using a physical, chemical and biological parameter complex. The international experience of water quality assessment was analyzed and the priority actions to implement the requirements of the Water Framework Directive in Ukraine were proposed.
\end{abstract}

Keywords: water quality, ecological regulation, monitoring, river basin

Submitted 18 June 2015, revised 19 January 2016, accepted 21 November 2016

\section{Introduction}

EU countries and Ukraine jointly prepared the Association Agreement, which was signed on the $27^{\text {th }}$ of June 2014 (PoU 2014). The Agreement foresees the implementation of a series of EU strategies into various sectors of the Ukrainian economy and creates a possibility to reform our economic activity significantly in accordance with international standards.

One of the areas of EU cooperation in the field of the environment is the improvement of water quality and water resource management. Water resource distribution within Ukrainian territory is very uneven; as a result some regions suffer from the scarcity of water of an acceptable quality for drinking and household needs. At the same time, irrational water use leads to further pollution caused by a household activity.

Some water bodies do not provide sufficient dilution of waste water - this is because of its intensive usage. As a result they lose the natural quality of water and ecosystem degradation takes place. The most notable examples of this are the Ukrainian rivers Uda and Poltva, which receive waste water from the cities of Lviv and Kharkiv.

In the 1980s, the degree of anthropogenic pressure reached a level which corresponds or exceeds the natural factors of the chemical composition of water bodies.

Water pollution is caused by almost all types of economic activity: industrial development, the growth of population and urban areas, the insufficient level of water treatment technologies, and others. Despite the fact that water resources are renewable natural resources, their exhaustion and pollution are noticeable all over. This problem is extremely vital for Ukraine because the human pressure here is higher than the corresponding rate in developed countries (PoU 2010a).

The water use is closely connected with quantitative indicators of water resources as well as their quality.

The European policy of interrelations in the water branch is regulated by numerous directives including Water Framework Directive - WFD (2000/60/EC), Drinking Water Directive (75/440/EEC). The Directive on the Treatment of Urban Wastewater (91/271/EEC) Nitrates Directive, Floods Directive and Marine Strategy Framework Directive are included in the Association Agreement.

The implementation of the abovementioned Directives in the practice of the water management in Ukraine requires the in-depth analysis and implementation of the corresponding legislative, institutional, organizational, methodological, and other, measures.

At the same time the assessment of water resource quality has significant difficulties because of the great differences of the methodological approaches in Ukraine and proposed ones in the WFD.

For a more detailed interpretation of the issue a detailed analysis of the Ukrainian and EU regulatory base on the water resource quality assessment and its status was made.

\section{Discussion}

\subsection{Surface water monitoring}

According to resolution of the Cabinet of Ministers of Ukraine No 391, dated with 30.03.1998, the following bodies are responsible for the monitoring of surface water: - Ministry of Ecology and Natural Resources of Ukraine 
(provides monitoring of water objects within preserved territories: background concentrations of pollutants including radionuclides).

- State Agency of Water Resources of Ukraine (responsible for monitoring of surface water at locations of main water intake facilities, at transboundary sections of water objects, on water objects located within the zones being under the influence of nuclear power stations, on water objects within the territories contaminated by radioactive substances). Agency provides monitoring of hydrochemical and radiological parameters.

- State Emergency Service of Ukraine (provides monitoring on sites of the State System of Hydrometeorological Observations on rivers, reservoirs and lakes: hydrochemical and hydrobiological parameters; radionuclides).

- Ministry of Agrarian Policy and Food of Ukraine (monitoring of surface water designated for agricultural use: toxicological and radiological parameters, residual amounts of pesticides, agrochemicals and heavy metals).

- State Sanitary-Epidemiological Service of Ukraine (monitoring of surface water within inhabited and recreational areas: chemical, bacteriological, radiological and virological parameters).

- State Agency of Ukraine on Exclusion Zone Management (monitoring of water objects in Chernobyl Nuclear Power Plant Exclusion Zone: pollutants and radionuclides in water; bioindicators in aquatic ecosystems).

All above mentioned bodies and agencies perform surface water monitoring on the basis of their programs according to specific goals and aims fixed in respective normative documents. It should be noted that these monitoring programs are not harmonized which in some cases leads to duplications and overlapping of sampling sites and dates of sampling. Reporting system is organized in such a way that each agency produces reports independently, manages their own databases and publishes monitoring data mostly upon request of higher authority.

Taking into account problems mentioned above Ministry of Ecology and Natural Resources of Ukraine has prepared the new Concept of reforming of the state monitoring system. According to the Concept organizational and structural scheme of informational support will be revised in line with requirements of European reporting system and international commitments of Ukraine

On 27 June, 2014 the EU-Ukraine Association Agreement was completely signed. The signature was followed by simultaneous ratification by the Verkhovna Rada and the European Parliament on 16 September 2014. In order of ensuring the realization of tasks in the sphere of European integration and implementation of Association Agreement the Cabinet of Ministers of Ukraine issued Decree \#346 dated with September 13, 2014. Decree states that organizational, expert, analytical and informational support of the Cabinet of Ministers of Ukraine affairs in the sphere of European integration is provided by the Governmental Office on European Integration of the Secretariat of the Cabinet of Ministers of Ukraine.

On April 15, 2016 the Cabinet of ministers of Ukraine has approved implementation plans of the Acts of EU environmental legislation including Implementation Plan of WFD. The main milestones of WFD Implementation Plan are the following (since 2014, when Association Agreement has come to force):

- Adoption of national legislation and designation of competent authority; adoption on legislative level of definition of the unit of Ukrainian territory's hydrographical zoning; development of provision on basin authority and definition of respective functions (3 years).

- Delineation of river basins districts and development of the managing mechanisms for international rivers, lakes and coastal waters; analysis of the characteristics of the river basins districts; implementation of the water quality monitoring programs (6 years).

- Implementation of the River Basins Management Plans, public consultations and publishing (10 years).

One of the significant steps toward transposition of EU legislation is the renewed Water Code which has been approved by the Parliament (Verkhovna Rada) on May 2016 as a first reading.

The WFD sets out the basic framework for the water management sector to prevent a further deterioration of water resource quality and to achieve a good status of it. It should be noted that the first steps of integrated river basin management implementation have already been made namely a hydrographical zoning of the Ukrainian territory was carried out and 8 river basin areas were identified (Fig. 1) (Grebin et al. 2013), river basin water management directorates were created as well. Basic characteristics of main river basins are presented in Table 1.

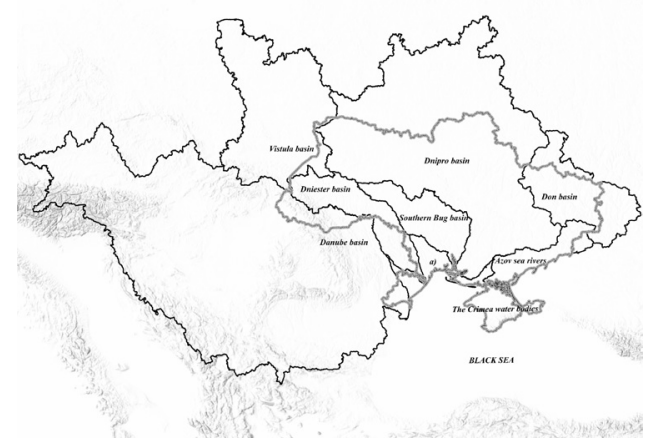

Fig. 1. Main river basins of Ukraine; a) - drainless area 
Table 1. Basic characteristics of the main Ukrainian river basisns

\begin{tabular}{|c|c|c|c|c|}
\hline & River basin & $\begin{array}{c}\text { Total area } \\
{\left[\mathrm{km}^{2}\right]}\end{array}$ & $\begin{array}{c}\text { Basin area within } \\
\text { the territory of Ukraine } \\
{\left[\mathrm{km}^{2}\right]}\end{array}$ & $\begin{array}{c}\text { Mean annual } \\
\text { discharge } \\
{\left[\mathrm{m}^{3} / \mathrm{s}\right]}\end{array}$ \\
\hline 1 & Dnipro & 504000 & 292700 & 1350,0 \\
\hline 2 & Danube & 817000 & 32350 & 6539,6 \\
\hline 3 & Dniester & 72100 & 52690 & 272,0 \\
\hline 4 & Southern Bug & & 63700 & 89,7 \\
\hline 5 & Don & 422000 & 54540 & 134,6 \\
\hline 6 & Vistula & 194424 & 76040 & 34,5 \\
\hline 7 & \begin{tabular}{|l} 
Sea of Azov rivers: \\
Molochna \\
Kalymius \\
Mius \\
Krynka \\
\end{tabular} & $\begin{array}{r}- \\
- \\
6680 \\
2634 \\
\end{array}$ & $\begin{array}{l}4650 \\
5030 \\
4890 \\
2540 \\
\end{array}$ & $\begin{array}{r}0,91 \\
11,0 \\
6,8 \\
6,1 \\
\end{array}$ \\
\hline 8 & $\begin{array}{l}\text { The Crimea rivers: } \\
\text { Salgyr } \\
\text { Belybek }\end{array}$ & $\begin{array}{l}- \\
-\end{array}$ & $\begin{array}{r}3750 \\
505\end{array}$ & $\begin{array}{l}2,14 \\
1,93\end{array}$ \\
\hline
\end{tabular}

\subsection{Water quality assessment}

The assessment of the water quality in Ukraine is based on a sanitary and hygienic background and the following indicators are used as target ones (PoU 1995):

- Maximum Allowable Concentration (MAC) of substances in water bodies, whose water is used for drinking, household and other needs of population;

- MAC of substances in water bodies for fishing;

- MAC of radioactive substances in water bodies, used for drinking, household and other needs of population.

The Hygienic standards of water quality are set for all types of water - surface, ground, drinking, hot water supply systems, and approved by the specially authorized state bodies in the field of the environmental protection, health and epidemiological supervision. The sanitary wellbeing in our country is governed by the Law On ensuring sanitary and epidemiological well-being of the population (PoU 1994), and the norms of Ukraine State Standard 4808 The sources of centralized drinking water supply. Hygienic and environmental requirements for water quality and the rules of removal, came into force in 2009 are used for drinking water supply (USS 4808), and sanitary rules and norms (SanRaN) adopted by the Ministry of Health (order No 400 of 12.05.2010), with amendments of 15.08.2011 (PoU 2010b) according to the Law on Drinking Water and Drinking Water Supply are also utilized (PoU 2002). The new edition of USS Drinking Water Requirements and Methods of Quality Control (USS 4808) have been developed. In total 11 microbiological, 5 organoleptic, 50 sanitary-toxicological and sanitary-chemical parameters are standardized. It should be noted that these national standards are based on the basis close to the World Health Organization approaches, the EU Drinking Water Direc- tive, the USA Safe Drinking Water Act and they take into account the threshold effect of toxic substances. As a result the MAC values of the pollutants are similar in different countries.

The abovementioned indicates that implementation of the EU Directive on drinking water will not cause significant problems for urban areas with water treatment plants. However, in rural areas centralized water pipes are usually absent, so people use wells, where the water does not pass through additional conditioning.

The MAC on the water which is used for fisheries $\left(\mathrm{MAC}_{\text {fish }}\right.$ ) is also based on sanitary-hygienic principles (The list of fish... 1999). The values of the mentioned MAC are used in Ukraine for the water quality assessment of surface water bodies (On the program of... 2002). This decision was based on the fact that the conditions for industrial fishing are acceptable for their food base and the ecological community on the whole. Taking into account that $\mathrm{MAC}_{\text {fish }}$ were established for the most sensitive part of the food trophic chain, some values are significantly below the $\mathrm{MAC}_{\text {drink. }}$. Characteristics of the surface water pollution in Ukraine have been calculated for the year 2013 (Table 2).

According to the results obtained with main ions, an isolated pollution $(<10 \%)$ is noted in most river basins, in the Southern Bug and Don basins - unstable pollution (10-30\%), for the Azov Sea rivers it has a dominant character $(>50 \%)$. The Nutrients pollution has a stable (from $30 \%$ to $50 \%$ of cases) or dominant character in almost all river basins. The worst situation is observed with heavy metals. All river basins have persistent pollution with this indicator.

These results clearly demonstrate that strictly regulatory rules are not supported by the obligation to maintain the law and thus confirm their declarative character. 
Table 2. The number of cases over the $\mathrm{MAC}_{\text {fish }}$ within the main river basins of Ukraine in 2013 ( $\%$ of total cases)

\begin{tabular}{|l|c|c|c|c|c|c|c|c|}
\hline \multirow{2}{*}{\multicolumn{1}{|c}{ Indicators }} & \multicolumn{9}{|c|}{ River basins } \\
\cline { 2 - 9 } & $\begin{array}{c}\text { The } \\
\text { Dnipro }\end{array}$ & $\begin{array}{c}\text { The } \\
\text { Danube }\end{array}$ & $\begin{array}{c}\text { The } \\
\text { Dniester }\end{array}$ & $\begin{array}{c}\text { The } \\
\text { South Bug }\end{array}$ & $\begin{array}{c}\text { The } \\
\text { Vistula }\end{array}$ & The Don & $\begin{array}{c}\text { The Azov } \\
\text { Sea rivers }\end{array}$ & $\begin{array}{c}\text { The Crimea } \\
\text { water bodies }\end{array}$ \\
\hline Main ions & $3-12$ & $1-2$ & $1-2$ & $19-26$ & $1-2$ & $17-28$ & $52-100$ & - \\
\hline Nutrients & 47 & 41 & 27 & 74 & 85 & 70 & $68-87$ & - \\
\hline Heavy metals & $61-95$ & $54-78$ & $54-69$ & $50-100$ & $28-90$ & $71-91$ & $75-99$ & $50-100$ \\
\hline Organic substances & $1-51$ & $2-20$ & $1-30$ & $2-46$ & $7-15$ & $1-52$ & $7-41$ & $2-3$ \\
\hline
\end{tabular}

The analysis of the existing practice in Ukraine regarding water quality assessment through the comparison of the factual concentration with the established MACs (both drinking and fishery) indicates a number of disadvantages of a systemic, biological and chemical character, which are the following:

- the hygienic norms of water quality cannot be applied for a whole water body, but only for water intake points and points of public water consumption;

- the MACs, established on sanitary and hygienic principles, are deprived from a universality and do not reflect the general toxicological pressure on the ecosystem, leaving aside many other aspects. Firstly, they are an exclusively individual standard set for one type of organism. The species toxic resistibility of hydrobionts depends not only on the specific action of the toxicant, but also on the level of the organism's organization. For example, the threshold concentration for various heavy metals varies for certain types of aquatic organisms by more than 100 (Maksimov 2000). Secondly, the MACs are always differentiated and concern individual chemical contaminants, therefore their use does not provide an integrated assessment of a water body. This disadvantage can be avoided by developing integrated chemical pollution indices - an index of water pollution and its subsequent variant of a combinatorial index of pollution, the indicator of chemical pollution;

- the sanitary and hygienic MACs make it possible to assess the degree of pollutant danger only through the total adaptive effects of the test organisms and do not take into account the effects of synergism and antagonism, which are always present in such integrated ecosystems like water (Gurman 1997);

- the biota response to the toxic stress does not have linear character because of the presence of compensatory mechanisms of living beings to adverse changes of the environment;

- the application of fishery norms for the whole water body had no sufficient justification because, as a rule, it is not used only for fish farming. The problem of the generalized integrated assessment of the ecosystem status is not being solved since regulatory actions con- cern only one, though, the highest level of a food chain (Volkov et al. 1996). The standards present in Ukraine are unified for all fish species, while in global practice they are separated for carp and salmon species. As a result the application of these norms will certainly lead to expenditure for increasing measures to minimize negative human impacts;

- the different trophic status of the ecosystem, the seasonal peculiarities of natural factors, which are the background for the display of the pollutant toxicity, are set aside during the justifying of MAC - that is, the law of natural geographical zoning is not considered;

- the concentration of the substances in water does not reflect a toxicological pressure on the ecosystem since it does not take into account the transformation processes of substances in water (the adsorption by a suspended matter and accumulation in sediments, the assimilation by biological objects, the processes of destruction, physical and chemical transformation and etc. that influences the bioavailability level both for hydrobionts and for human beings (Methodological guidelines... 1984).

Using MACs it is impossible to establish the specific functioning of water ecosystems in different natural climatic zones, and their seasonal peculiarities. The region geochemical diversity is ignored. It is clear that during a long period the hydrobiont populations have already adapted to life in different geochemical provinces and to the regional composition of the chemical ingredients as well. The imperfection of a sanitary and hygienic methodology for water quality assessment in Ukraine can be clearly demonstrated in the example of such pollutants as heavy metals (HM). This problem is widely presented in scientific publications. The water quality assessment on HM for which strict rules are established today has a lot of uncertainties. The materials presented in various scientific publications indicate that MAC is exceeded by $10-100$ times on different metals in $70-90 \%$ cases in the surface water of Ukraine. As a result, public opinion about the total natural water resource pollution on HM was formed.

The discordance between the HM geochemical background in natural water resources which is determined by 
a chemical element composition in geological rocks, soils and their MAC values was displayed. At the same time, the assessments made on environmental quality standards demonstrate a good (in some cases moderate) water quality status. This is because of natural water mechanisms which reduce the physiological activity and toxicity of metals, converting them into forms unavailable for the organism that can't penetrate through the cell membrane. The inverse situations are seen when the ecological status of water bodies is poor, but the MAC values are not exceeded. The mentioned facts indicate that water quality assessment based on the MAC has methodological disagreement, because the analytical determination of the total metal content is compared with the MAC value that is established by the ionic form of the metal $\left(\mathrm{Cu}^{2+}, \mathrm{Fe}^{3+}, \mathrm{Ni}^{2+}\right.$, etc). At the same time, heavy metals migrate in natural waters both in suspended and dissolved forms. The dissolved forms are presented as hydrated ions, ion pairs, and a wide range of complex compounds with organic and inorganic ligands. Today a lot of data demonstrates different physiological activity of the physical and chemical forms of heavy metals and their ability to penetrate through the cell membrane. Let us consider the case of copper. Its MAC value is $0.001 \mathrm{mg} / 1$, while its content in natural water is at least 3-5 times higher. This disagreement leads to biased conclusions about anthropogenic water pollution.

The given arguments demonstrate that the operating MAC system is rigid and does not provide a reliable water quality assessment and often leads to excessive severity of norms, and as a result to unreasonable expenditure for their implementation. Hereupon the massive violation of the mentioned norms is observed all over the country.

At the same time it should be emphasized that the abovementioned disparity does not indicate the lack of hygienic norm reliability. Its use is absolutely reasonable for the water sanitary-hygienic assessment for drinking, household and hygienic purposes, while its application for an integrated water body state assessment does not provide an adequate characteristic of water ecosystem conditions, as mentioned above.

To overcome the mentioned disadvantage it is necessary to take into account the pollutant impact not only on individual organisms and groups but on the population as a whole. This approach is widespread in global practice for the rational limitation of human impact and it is being solved by environmental regulation.

The first step to this transition in the USSR was a method developed in the 1960s by Bylinkina (1962) and Drachyov (1964).

This method included 5 physicochemical, 6 chemical, 5 microbiological and 5 hydrobiological parameters.
Many more water ecosystem components were covered by the Method of surface water quality environmental assessment by appropriate categories approved by the Ministry of Environmental of Ukraine as the inter-agency steering regulations in 1998 (Romenko et al. 1998). The method consists of three groups of specialized classifications: by the salt content, trophic saprobiological criteria and the contents of specific substances (toxic and radioactive exposure).

The first one contains two components: a salinity identification by mineralization degree and class identification, and species and group definition by the basic ions correlation. Index $I_{1}$ is defined on these parameters basis.

The trophic saprobiological assessment is implemented based on the complex of indicators that include hydrophysical (suspended matter, transparency), hydrochemical $(\mathrm{pH}$, mineral forms of nitrogen, phosphorus, phosphate, oxygen, chemical and biological oxygen demand (COD, BOD), hydrobiological parameters (phytoplankton biomass, self-purification- self-pollution index), bacteriological (number of bacterioplankton and saprophytic bacteria), and saprobic indices. Index $I_{2}$ is defined on the basis of these parameters.

The assessment based on the substances of specific action includes the data on the presence of mercury, cadmium, copper, zinc, lead, chromium, nickel, iron, manganese, fluorides, cyanide, petroleum hydrocarbons, volatile phenols, surfactants, pesticides, total $\beta$-activity, and concentrations of cesium-137 and strontium-90. On the grounds of these parameters, index $I_{3}$ is defined.

The classifications for the assessments, which include 5 classes and 7 categories of the water quality, were developed.

Defining classes and categories of the water quality on some parameters consists of the following:

1. The average values of each parameter separately compared with the corresponding categories of the water quality.

2. The worst values of each parameter compared with the corresponding categories of the water quality.

3. Based on the comparison of each parameter, water quality categories are determined on average and the worst parameters.

4. Average parameters are calculated by blocks $I_{1}$ (mineralization), $I_{2}$ - trophy and saprobiologycal index, $I_{3}-$ Index of the specific action.

The phase of information synthesis is performed by defining the integral values of water classes and categories within the respective blocks: $I_{1}-$ Index of salt content; $I_{2}$ - ecology-sanitary (trophy-saprobiological) index; $I_{3}-$ Index of specific indicators of toxic effects. 
Based on the integration of the elementary features of each group, generalized indicators, their trophicity and saprobity are defined. Five classes are appointed for their status (high, good, moderate, poor and bad). On their grade (purity) - 5 classes and 7 categories (very clean, clean (categories clean and moderate clean), polluted (category slightly polluted and moderately polluted), dirty and very dirty. To simplify the analysis the environmental index $I_{E}$ is calculated as the arithmetical mean of the indices $I_{1}, I_{2}, I_{3}$.

The undoubted advantage of this method is generalizing the assessment of complex physical, chemical and biotic indices.

At the same time, the practice of its application in Ukraine shows that none of the public monitoring systems provide the list of required measurable indicators which are included in the classification.

Physical and chemical parameters are the most presented data but hydrobiogical data as a rule are missing. Thus, all the advantages of this method decrease. In addition, the method has a number of uncertainties. In the calculation of block indices fractional numbers are often formed whereas the method operates on integer-values.

However, this disadvantage can be easily avoided by introducing a graphical dependency of the water category from the value of the corresponding index.

It is unclear from this methodology how individual indices are related among themselves. This is of a particular importance when the categories of quality diametrically differ by different ingredients. What result should be chosen in this case? Arithmetic averaging leads to the hiding of pollution problems. The integrated environmental index $\left(I_{E}\right)$ is calculated by a simple additive manner that does not take into account the "weight" of different components in the water pollution.

In fact, the mentioned demerits deprive this methodology of comprehension properties. Moreover, they do not present the issue on the reliability of the class definition and quality category.

Thus, there is an urgent need to reform governance in the field of the water resource management in Ukraine that is reflected in the Law of Ukraine On the Basic Principles of the State Environmental Policy of Ukraine till 2020 (PoU 2010a). The national adaptation strategy of water management to international practice in connection with signing the Association Agreement with the EU will be realized through the implementation of appropriate EU Directives. As a country of the Danube river basin and a member of the International Commission for the Danube River Protection (ICPDR), Ukraine is involved in the practical implementation of the WFD and has gained some experience.
According to the WFD the main characteristic of the aquatic environment is the ecological status of the aquatic ecosystem, while for Ukraine the content of the individual components is used as a rule. As is known, hydro-ecological system status is determined by its abiotic (physical and physico-chemical) and biotic indicators, correspondingly the ecological status is set by biological components together with physico-chemical and hydromorphological characteristics

The advantage of abiotic indicators is measuring them by analytical procedures, the results of which are presented as fixed values. This gives a possibility to assess accurately the water pollution on the specific substance and characterize the habitat of aquatic organisms.

The fixed values of contamination allow the establishment of correspondence parameters with regulatory values.

The measurement of physico-chemical parameters allow the establishment of quickly limiting parameters of ecosystem pollution in the case of the illegal discharge.

One of the disadvantages of physical and chemical parameter usage is the high cost of analytical procedures, and also that it needs a great amount of special equipment. Furthermore, hazardous toxicants can affect living organisms at the concentrations below the limit of the analytical method. The use of only physico-chemical parameters cannot allow the characterization of the chemical effect on living organisms; this especially concerns the components which significantly transform in the aquatic environment. As an example, a water colour parameter is standardized by the organoleptic property. A colour is mainly determined by the presence of humic acids in the water that are considered harmless for living organisms. However, chlorination, applied in Ukraine during a drinking water treatment, results in the formation of secondary chloricderivatives that have carcinogenic properties. As for the heavy metals mentioned above, their normalization in the water is realized on a toxicological principle. The processes of physical and chemical transformations of the metals in the aquatic environment further the reduction of their toxicity and ability to penetrate into the cell membrane.

These disadvantages can be eliminated by involving the biological indicators that give an integrated characteristic of the pollutant impact, taking into account an adaptive possibility of organisms and the interior aquatic transformational changes and interphase substance transitions. They characterize the degree of the ecosystem deviation from equilibrium, a reference status, but not the parameters of outside influence.

The reaction of a biological component to pollution can be more prolonged compared with abiotic parameters. 
According to the WFD, the definition of an ecological status of natural waters is realized on biological indicators, hydro-morphological, physico-chemical and chemical parameters.

The ongoing monitoring system of the surface water bodies in Ukraine focuses first of all on chemistry parameters of the water. The definition of biotic and hydromorphological parameters is performed only on the state network of hydro-meteorological observations, but their number mismatches the list referred to in the WFD, and concerns only saprobic indices, water discharge and suspended sediments.

As for hydro-chemical parameters, their list is usually limited by the parameters of a general physico-chemical status. The investigation of the most hazardous pollutants is not carried out; it especially concerns xenobiotics, which is connected with a significant developmental lag of the analytical base and the high cost of operations. At the same time, special investigations indicate the presence of hazardous contaminants in the surface water. For example, cadmium, lead, nickel, and synthetic organic compounds: alachlor, pentabromodifenil ether, hlorpirifos, hexachlorobenzene, pentahlorobenzol, polyaromatic hydrocarbons and tryfluralin were found in the water of the South Bug (Research monitoring... 2012). Despite a recently adopted new edition of SanRaN, in which the strict standards of MAC for 94 values were determined, the monitoring system is unable to keep these norms (PoU 2010b).

Thus, the relevant national informational basis is unable to provide the determination of the ecological status of water bodies.

\section{Conclusions}

The analysis of the practical results of water quality assessment and numerous fundamental investigations demonstrate the ineffectiveness of a national working system of the surface water pollution regulation, which is based on hygienic and sanitary norms.

To improve a water quality evaluation system its methodology should be changed, the transition from hygiene and sanitary approaches to environmental regulation has to be carried out - that is the issue of the day in the water management policy. It is also should be underlined that for reliable assessment of water quality the respective internationally harmonized monitoring programs are of high importance. Currently the international surface water monitoring in Ukraine is being done within the framework of bilateral agreements with neighboring countries sharing transboundary river basins. The State Agency of Water Resources of Ukraine is one of the main players in this field. There is a number of Basin Water Resources Directorates functioning under subordination to the Agency and cooperating with respective organizations in neighboring countries, for instance:

- Desna Basin Water Resources Directorate (UkraineRepublic of Belarus);

- Dnister-Prut Water Resources Directorate (UkraineRepublic of Moldova-Romania);

- Danube Water Resources Directorate (Ukraine-Republic of Moldova-Romania);

- Western Bug Water Resources Directorate (UkrainePoland);

- Tisza River Water Resources Directorate (UkraineSlovakia-Hungary-Romania).

As a party to International Comission for the protection of the Danube River (ICPDR) Ukraine participates to TransNational Monitoring Network. The TransNational Monitoring Network (TNMN) was established to support the implementation of the Danube River Protection Convention in the field of monitoring and assessment. The TNMN was formally launched by the ICPDR in 1996. Ukraine provides annually data on chemical composition of water at transboundary stations on rivers Tisza, Latorytsya, Uzh, Prut, Siret and Ukrainian section of the Danube.

However, implementation of the WFD for integrated river basin management in Ukraine requires significant organizational and material expenditure to obtain initial information for the ecological status determination of water bodies.

This is because the monitoring system of surface water is provided only with the indicators of a physical and chemical composition, but the priority pollutants are not included in the list of definable components due to the lack of the appropriate analytical equipment. The hydrobiological monitoring is realized only by the state hydro-meteorological network of observation, but neither the frequency nor the list of indicators meets the regulatory requirements of the WFD. The hydromorphological observations are limited by determining water discharge and suspended sediments.

Consequently, to transform the transition of Ukraine to an ecological valuation of water quality, the problem of harmonizing the monitoring system's ongoing state to the WFD methodology requirements should be solved immediately, during the initial period of transformation of national legislation, namely:

I. The implementation of hydro-biological monitoring with the defining of the following parameters:

a) The composition and abundance of aquatic flora;

b) The composition and abundance of benthic invertebrate fauna; 
c) The composition, abundance and age structure of fish fauna.

II. The improvement of a hydro-chemical monitoring (concerning the list of components and frequency of sampling) - temperature, oxygen conditions $\left(\mathrm{O}_{2}\right.$, $\mathrm{BOD}, \mathrm{COD}_{\mathrm{Cr}}, \mathrm{COD}_{\mathrm{Mn}}$ ), salinity (salinity/mineralization, conductivity), $\mathrm{pH}$, nutrient conditions (total $\mathrm{N}$, $\mathrm{N}-\mathrm{NH}_{4}^{+}, \mathrm{N}-\mathrm{NO}_{3}{ }^{-}, \mathrm{N}-\mathrm{NO}_{2}{ }_{2}$, total P, P-PO ${ }_{4}{ }^{3-}$ ), specific pollutants (pollution by all priority substances identified as being discharged into the body of water (the first year - all substances, later - only those which are found in it, pollution by other substances identified as being discharged in significant quantities into the body of water).

III. The implementation of full-scale hydro-morphological monitoring with an appropriate frequency of the hydrological parameter determination.

a) To use a special scientific monitoring for the assessment of water bodies in the transition period.

b) To define the reference values as a target index and develop the type-specific classifications of the main biotic and abiotic parameters in accordance with the typology of river basins.

c) To introduce reporting to the State Register of Sewage Water (national statistical form of the Water Cadastre) according to a full list of the pollutants identified in the water body, including the priority indicators.

d) To develop the methodology and to implement the assessment of pollutant loading from diffusive sources in the river basins. Reliable assessment requires a detailed monitoring program, without it will not be sufficient database for evaluation, identification of pollutants.

Bibliography

75/440/EEC, Council Directive of 16 June 1975 concerning the quality required of surface water intended for the abstraction of drinking water in the Member, The Council of the European Communities, EUR-Lex, Brussels

91/271/EEC, Council Directive of 21 May 1991 concerning urban waste-water treatment, The Council of the European Communities, EUR-Lex, Brussels

2000/60/EC, Directive of the European Parliament and of the Council of 23 October 2000 establishing a framework for Community action in the field of water policy, The Council of the European Communities, EUR-Lex, Brussels

Bylinkina A.A., 1962, On devices graphic analysis on the state of the water, (in Russian), [in:] Proceedings of the $16^{\text {th }}$ Meeting of Hydrochemical Institute of USSR Academy of Sciences,
A.A. Bylinkina, S.M. Drachyov, A.I. Itskova (eds.), Novocherkask, AN SSSR, 8-12

Drachyov S.M. 1964, Pollution control of rivers, lakes and reservoirs, industrial and domestic sewage, (in Russian), USSR Academy of Sciences, Leningrad, 274 pp.

Grebin V., Mokin V., Stashuk V., Khilchevsky V., Yatsyuk M., Chunarov O., Kryzhanivsky S., Babchuk V., Yaroshevych O., 2013, Hydrographical and water-economic zoning methodology of the territory of Ukraine in accordance with the EU Water Framework Directive requirements, (in Ukrainian), Interpres Ltd, Kiev, 55 pp.

Gurman A.X., 1997, Water quality standards (in Russian), [in:] Monitoring of the environment, A.X. Gurman (ed.), 203-215 Maksimov V.N., 2000, Determination analysis in ecosystems: conjugation for biotic and abiotic components, (in Russian), News of Russian Academy of Sciences, 24, 482-491

Methodological guidelines for experimental study of the processes of chemical compounds transformation in their water hygienic regulation, (in Russian), 1984, No 2966-84, USSR Ministry of Health, Moscow, 24 pp.

On the program for improving the quality of basic observations of pollution and environmental monitoring, (in Ukrainian), 2002, Decree of the Ministry of Ecology and Natural Resources of Ukraine No 57 dated 08.02.2002

Parliament of Ukraine, 1994, On Ensuring Sanitary and Epidemiological well-being of population, (in Ukrainian), Law of 24.02.1994, No 4004-XII, available at: http://zakon2.rada. gov.ua/laws/show/4004-12

Parliament of Ukraine, 1995, Water Code of Ukraine, (in Ukrainian), Official Text of 06.06.1995, available at: http://zakon2. rada.gov.ua/laws/show/213/95-вр

Parliament of Ukraine, 2002, On Drinking Water and Water Supply, (in Ukrainian), Law of 10.01.2002, No 2918-III, available at: http://zakon0.rada.gov.ua/laws/show/2918-14

Parliament of Ukraine, 2010a, On the Basic Principles (Strategy) of the State Environmental Policy of Ukraine for the period up to 2020, (in Ukrainian), Strategy of 21.12.2010, No 2818-VI, available at http://zakon4.rada.gov.ua/laws/ show/2818-17

Parliament of Ukraine, 2010b, State sanitary rules and regulations. Hygienic requirements for drinking water for human consumption, (in Ukrainian), DSanPiN 2.2.4-171-10 of 12.05.2010, available at: http://zakon4.rada.gov.ua/laws/show/z0452-10

Parliament of Ukraine, 2014, The Association Agreement between Ukraine and the European Union and its Member States, (in Ukrainian), available at: http://comeuroint.rada. gov.ua/komevroint $/$ doccatalog $/$ document?id=56219

Research monitoring to detect priority pollutants within the South Bug river basin. Report, (in Ukrainian), 2012, Project supported by the Swedish Environmental Protection Agency: Strengthening Management of the South Bug river basin. 
Romanenko V.D., Zhukynskyy V.N., Oksiyuk O.P., et al., 1998, Methods of environmental assessment of surface water quality by the appropriate categories, (in Ukrainian), Kyiv: Symbol - T, 28 pp.

The list of fish industry norms: maximum allowable concentration (MAC) and tentatively safety impact levels (TSIL) of unhealthy substances in water of water bodies used for fishery, (in Russian), 1999, M: VNYYRO, 304 pp.
Ukrainian State Standard 4808, 2007, Sources of centralized drinking water supply. Hygienic and environmental requirements for water quality and the rules of remove of 05.07.2007, (in Ukrainian), available at: http://minregion. gov.ua/attachments/files/zhkh/text.pdf

Volkov I.V., Zalicheva I.N., Shustova N.K., 1996, Is there an environmental sense in general federal fishery MACs?, (in Russian), Ecology, 5, 350-354 
